\title{
Międzynarodowa konkurencyjność litewskiej gospodarki a jej kapitał ludzki
}

Erika Višnievskytė*

\section{Wstęp}

Pojęcie konkurencyjności międzynarodowej często pojawia się w literaturze ekonomicznej, a posiadanie konkurencyjnej gospodarki uznaje się obecnie za najważniejszy cel każdego kraju. W ogólnym rozumieniu konkurencyjność to zdolność gospodarki do rywalizacji na światowych rynkach. Zgodnie z definicją Światowego Forum Ekonomicznego (WEF) konkurencyjność gospodarki to zestaw czynników, polityk oraz instytucji określających poziom produkcyjności w kraju. Obecnie o konkurencyjności w coraz większym stopniu decydują jakościowe determinanty związane m.in. z innowacjami, postępem technologicznym, systemami zarządzania oraz kapitałem ludzkim. Kapitał ludzki wydaje się szczególnie ważnym elementem kształtowania konkurencyjności międzynarodowej.

Celem niniejszego artykułu jest przedstawienie kapitału ludzkiego Litwy jako jednego z czynników, które miały istotny wpływ na pozycję litewskiej gospodarki w latach 2006-2016, jeśli chodzi o konkurencyjność międzynarodową. W ten sposób wyznaczony został zakres problemowy artykułu. W pierwszej części artykułu zostaną przedstawione podstawowe pojęcia dotyczące konkurencyjności międzynarodowej oraz kapitału ludzkiego na podstawie literatury zagranicznej oraz polskiej. W kolejnej części przeanalizowane zostaną zmiany pozycji konkurencyjnej gospodarki litewskiej w latach 2006-2016 na podstawie Indeksu Globalnej Konkurencyjności opracowanego przez ekspertów WEF. W ostatniej części, trzeciej, zostanie przeprowadzona analiza kapitału ludzkiego Litwy; wskazane zostaną także obszary wymagajace poprawy.

\footnotetext{
* Erika Višnievskytè - licencjat, Uniwersytet w Białymstoku, Wydział Ekonomiczno-Informatyczny w Wilnie, Koło Naukowe Studentów Ekonomii im. F. A. von Hayeka, kierunek studiów: Ekonomia, erika.visnievskyte@gmail.com.
} 


\section{Międzynarodowa konkurencyjność gospodarki i kapitał ludzki w ujęciu teoretycznym}

W literaturze przedmiotu nie przyjęto jednej powszechnie obowiązującej definicji konkurencyjności gospodarki. W ogólnym rozumieniu konkurencyjność to zdolność gospodarki do rywalizacji na światowych rynkach, czasem definiowana też jako zdolność do długookresowego wzrostu gospodarczego. Jest ona szczególnie ważna w procesie globalizacji. Konkurencja gospodarcza jest rywalizacją podmiotów mających na celu osiągnięcie korzyści związanych z działalnością gospodarczą na rynku krajowym i międzynarodowym. Podmiotami uczestniczącymi w tej rywalizacji są zarówno osoby prowadzące działalność gospodarczą, przedsiębiorstwa, korporacje transnarodowe, jak i państwa oraz samorządy i regiony. Przedmiotem, obszarem rywalizacji gospodarczej jest zarówno rynek produktów i usług finalnych, jak i rynek czynników produkcji, tj. pracy, kapitału, technologii (Bossak, Bieńkowski 2004, s. 17).

W stosunkach międzynarodowych areną walki konkurencyjnej, w której głównymi aktorami są przedsiębiorstwa, korporacje transnarodowe i państwa, jest rynek światowy. A konkurencyjny jest ten kraj, który podejmuje działania sprzyjające przedsiębiorczości, konkurencji, zwiększeniu akumulacji kapitału oraz innowacyjności i efektywności mechanizmów rynkowych, a więc zwiększeniu produktywności i rentowności działalności gospodarczej (Bossak, Bieńkowski 2004, s. 20). Szeroki przegląd definicji można spotkać w opracowaniach Józefa Misali (Misala 2007, s. 21-24); niektóre z nich przedstawiono w tabelach 1 i 2.

Tabela 1. Wybrane definicje międzynarodowej konkurencyjności gospodarki w literaturze zagranicznej

\begin{tabular}{|c|l|l|}
\hline Rok & Autor / instytucja & Definicja \\
\hline 1985 & $\begin{array}{l}\text { Komisja Wspól- } \\
\text { not Europejskich }\end{array}$ & $\begin{array}{l}\text { Konkurencyjność krajów to ich zdolność do zachowania równo- } \\
\text { wagi na rynku krajowym między importerem a produkcją krajową, } \\
\text { która to równowaga jest w zgodzie z efektami uzyskanymi w eks- } \\
\text { porcie (European Commision). }\end{array}$ \\
\hline 1988 & $\begin{array}{l}\text { J. Fagerberg } \\
1994\end{array}$ & $\begin{array}{l}\text { Zdolność danego kraju do osiągania podstawowych celów gospo- } \\
\text { darczych, zwłaszcza odpowiedniego tempa wzrostu gospodarcze- } \\
\text { go i wysokiej stopy zatrudnienia przy unikaniu trudności z równo- } \\
\text { wagą bilansu płatniczego (Borowski 2015, s. 27). }\end{array}$ \\
\hline $\begin{array}{l}\text { Gospodarczego } \\
\text { Giedzynarodowy }\end{array}$ & $\begin{array}{l}\text { Zdolność kraju do tworzenia wartości dodanej i w ten sposób pod- } \\
\text { noszenia bogactwa narodowego poprzez odpowiednie zarządzanie } \\
\text { zasobami i procesami, atrakcyjnością i agresywnością, uwzględ- } \\
\text { niając wymiar globalny i lokalny, oraz integrowanie tego wszyst- } \\
\text { kiego w jednolity, spójny model ekonomiczny i społeczny (IMD, } \\
\text { World World Competitiveness Yearbook). }\end{array}$ \\
\hline
\end{tabular}




\begin{tabular}{|l|l|l|}
\hline Rok & Autor / instytucja & Definicja \\
\hline 1996 & $\begin{array}{l}\text { Organizacja } \\
\text { Współpracy } \\
\text { Gospodarczej } \\
\text { i Rozwoju } \\
\text { (OECD) }\end{array}$ & $\begin{array}{l}\text { Polityka międzynarodowej konkurencyjności oznacza wspiera- } \\
\text { nie zdolności przedsiębiorstw, przemysłów, regionów, narodów } \\
\text { i ponadnarodowych ugrupowań do generowania, w warunkach } \\
\text { konieczności, możliwie największych przychodów za pomocą } \\
\text { czynników wytwórczych przy ich możliwie największym wyko- } \\
\text { rzystaniu (OECD). }\end{array}$ \\
\hline 2006 & $\begin{array}{l}\text { Śliatowe } \\
\text { Forum } \\
\text { Ekonomiczne }\end{array}$ & $\begin{array}{l}\text { Zestaw czynników, polityk i instytucji, które określają poziom pro- } \\
\text { dukcyjności w kraju i powodujących, że gospodarka narodowa jest } \\
\text { w stanie rozwijać się względnie szybko w ujęciu średnio- i długo- } \\
\text { okresowym (World Economic Forum). }\end{array}$ \\
\hline
\end{tabular}

Źródło: opracowanie własne.

Tabela 2.Wybrane definicje międzynarodowej konkurencyjności gospodarki w polskiej literaturze fachowej

\begin{tabular}{|l|l|l|}
\hline Rok & Autor & Definicja \\
\hline 1995 & W. Bieńkowski & $\begin{array}{l}\text { Zdolność do walki o ekonomiczne przetrwanie w warunkach za- } \\
\text { ostrzającej się konkurencji (Radło 2008). }\end{array}$ \\
\hline 2000 & J. W. Bossak & $\begin{array}{l}\text { Konkurencyjność kraju można określić jako takie kształtowanie } \\
\text { się warunków instytucjonalnych, makroekonomicznych warun- } \\
\text { ków konkurencji oraz sprawności mechanizmu rynkowego, któ- } \\
\text { re buduje podstawy ekonomiczne dynamicznego rozwoju kraju } \\
\text { i przedsiębiorstw w zmieniającym się otoczeniu (Bossak, Bień- } \\
\text { kowski 2004). }\end{array}$ \\
\hline 2001 & K. Żukrowska & $\begin{array}{l}\text { Przez pojęcie konkurencyjności należy rozumieć zdolność przy- } \\
\text { stosowania się gospodarki, a raczej działających w niej podmiotów } \\
\text { albo ich produkcji, do zmieniających się warunków, pozwalajacą } \\
\text { utrzymać lub poprawić ich pozycję na runku w warunkach global- } \\
\text { nych (Misala 2007). }\end{array}$ \\
\hline 2003 & L. J. Jasiński & $\begin{array}{l}\text { Konkurencyjność krajów to ,swego rodzaju średnia konkuren- } \\
\text { cyjności działających w nich przedsiębiorstw oraz rozwiązania } \\
\text { instytucjonalne wpływające istotnie na zdolność sprostania presji } \\
\text { rynkowej przez powstające na danym terenie dobra i usługi” (Mi- } \\
\text { sala 2007). }\end{array}$ \\
\hline
\end{tabular}

Źródło:opracowanie własne.

Z przytoczonych wybranych definicji konkurencyjności międzynarodowej gospodarek wynika, na jej kształt ma wpływ wiele czynników. Dlatego należy wybrać jednen lub kilka czynników, które mają obecnie istotne znaczenie dla międzynarodowej konkurencyjności gospodarek. Jeśli dane zjawisko zależy od wielu czynników, zawsze znajdą się wśród nich te, które są dla niego decydujące. Uwzględnienie większej liczby czynników miało udoskonalić badania konku- 
rencyjności prowadzone przez różne instytucje międzynarodowe, np. Światowe Forum Ekonomiczne, Fundację Bertelsmanna czy Międzynarodowy Instytut Zarządzania.

Najbardziej kompleksowe badanie jest prowadzone przez Światowe Forum Ekonomiczne - obejmuje ono ponad 140 gospodarek współczesnego świata. Sporządzając indeksy konkurencyjności dla poszczególnych gospodarek, na podstawie których powstaje ranking konkurencyjności globalnej, WEF bierze pod uwagę dane dwojakiego rodzaju. Po pierwsze, są to dane liczbowe, np. dotyczące wskaźników makroekonomicznych, wskaźników skolaryzacji, ilościowych parametrów szeroko rozumianej infrastruktury. Po drugie, są to dane jakościowe będące efektem badań ankietowych przeprowadzanych wśród członków zarządów firm działających w danym kraju (Falkowski 2013, s. 29-30). Według WEF konkurencyjność gospodarcza krajów opiera się na 12 filarach. Są to:

1) instytucje,

2) infrastruktura,

3) otoczenie makroekonomiczne,

4) zdrowie i edukacja na poziomie podstawowym,

5) wyższe wykształcenie i doskonalenie zawodowe,

6) efektywność rynku dóbr,

7) efektywność rynku pracy,

8) poziom rozwoju rynku finansowego,

9) przygotowanie technologiczne,

10) rozmiar rynku,

11) wyrafinowanie środowiska biznesowego,

12) innowacyjność.

Podobnie jak w przypadku konkurencyjności, mamy do czynienia z mnogością definicji kapitału ludzkiego. Jedni autorzy mówią o życiu człowieka jako kapitale, inni jako zasób kapitału traktują ludzi, którzy wraz ze swoją wiedzą, umiejętnościami i zdrowiem stanowią wartość, a jeszcze inni wskazują na kapitał ucieleśniony w człowieku (Wronowska 2012, s.19).

Zgodnie z definicją S. R. Domańskiego kapitał ludzki to zasób wiedzy, zdrowia, umiejętności i energii witalnej zawarty w danym społeczeństwie. Kapitał ludzki jest zasobem będącym źródłem przyszłej satysfakcji, zarobków czy usług o jakiejś wartości. Kapitał ludzki wyrożnia to, że jest on częścią człowieka, jest ludzki - ucieleśniony w ludziach. Może być gromadzony nie tylko jako aktywa, które są nabywane na rynku, ale w wyniku inwestowania w siebie. Żadna osoba nie może oddzielić od siebie kapitału, który posiada (Domański 1993, s. 19).

Według twórcy teorii kapitału ludzkiego T. W. Schultza kapitał ludzki to atrybuty populacji mające określoną wartość, którą można zwiększać poprzez właściwe inwestowanie (Schultsz 1981, s. 21). Także zdaniem M.G. Woźniaka kapitał ludzki jest atrybutem jednostki ludzkiej. Obejmuje kompetencje i umiejętności pracowników istotne w działalności gospodarczej, a także zdrowie, które wpływa 
na ich produktywność. Jego właścicielami są podmioty ekonomiczne, reprezentujące różne grupy interesów i aktywności gospodarczej, czyli pracownicy, klienci, dostawcy i wszystkie inne osoby związane umowami z organizacjami gospodarczymi (Woźniak 2008, s. 127).

T. Listwan kapitał ludzki określił jako kapitał należący do zasobów niematerialnych i stanowiący najważniejszą część kapitału intelektualnego. Kapitał ludzki definiowany jest jako zbiór właściwości tkwiących w ludziach, takich jak umiejętności, doświadczenie zawodowe, wiedza, cechy psychologiczne, zachowania i zdrowie. Właściwości te mają określoną wartość i charakter jakościowy. Wpływając na wydajność i efekty pracy, mogą być źródłem przyszłych zarobków, satysfakcji zarówno dla pracownika, jak i dla otoczenia, w jakim się znajduje (Listwan 2005, s. 57).

Z przedstawionych definicji jednoznacznie wynika, że kapitał ludzki jest ważną częścią każdego człowieka. Umiejętności, zasób wiedzy, zaradność, intuicja, talent, kreatywność, zdrowie i energia witalna zawarte w człowieku, odpowiednio pomnażane przez konkretne inwestycje, mają też ogromne znaczenie dla rozwoju gospodarczego danego kraju.

Tabela 3. Czynniki kształtujące kapitał ludzki

\begin{tabular}{|c|c|}
\hline \multicolumn{2}{|c|}{ Eukacja } \\
\hline 1 & Publiczne wydatki na edukację jako \% PKB \\
\hline 2 & Liczba uczniów przypadających na jednego nauczyciela \\
\hline 3 & Wskaźnik skolaryzacji brutto dla wychowania przedszkolnego \\
\hline 4 & Wskaźnik skolaryzacji brutto dla szkolnictwa średniego \\
\hline 5 & Wskaźnik skolaryzacji brutto dla szkolnictwa wyższego \\
\hline 6 & Liczba lat poświęconych na naukę \\
\hline \multicolumn{2}{|c|}{ Rynek pracy } \\
\hline 7 & Stopa bezrobocia \\
\hline \multicolumn{2}{|c|}{ Nauka } \\
\hline 8 & Liczba osób pracujących w sektorze $\mathrm{B}+\mathrm{R}$ na 1 milion mieszkańców \\
\hline 9 & Wydatki na $\mathrm{B}+\mathrm{R}$ jako \% PKB \\
\hline 10 & Liczba zarejestrowanych patentów przez mieszkańców \\
\hline \multicolumn{2}{|c|}{ Wysokie technologie } \\
\hline 11 & Liczba komputerów na 1000 osób \\
\hline 12 & Użytkownicy internetu na 1000 osób \\
\hline 13 & Eksport wysokich technologii jako \% produkcji na eksport \\
\hline \multicolumn{2}{|c|}{ Zdrowie } \\
\hline 14 & Wydatki na ochronę zdrowia jako \% PKB \\
\hline
\end{tabular}

Źródło: opracowanie własne. 
Kapitał ludzki skupia w sobie wiele ważnych elementów decydujących o zdolnościach produkcyjnych każdego człowieka. Należą do nich m.in.: wiedza i wykształcenie, umiejętności i kwalifikacje, predyspozycje i doświadczenia, a także cechy psychomotoryczne oraz stan zdrowia czy poziom zmęczenia.

Istotnym elementem kapitału ludzkiego jest także stan zdrowia. $Z$ literatury przedmiotu wynika, że determinuje on produktywność zdobytych przez pracowników wiedzy, kwalifikacji i umiejętności, a także poziom zaangażowania innych czynników wytwórczych - kapitału rzeczowego i technologii. Aby zwrócić uwagę na istotną rolę zdrowia, w literaturze przedmiotu zdrowie określa się nie tylko jako składnik kapitału ludzkiego, lecz także jako odrębny czynnik wytwórczy - kapitał zdrowia (Firszt, Jabłoński 2016, s. 53-54).

\section{Analiza konkurencyjności międzynarodowej litewskiej gospodarki w latach 2006-2016}

W niniejszym rozdziale zostaną zaprezentowane wyniki analizy konkurencyjności litewskiej gospodarki na tle krajów bałtyckich, Estonii i Łotwy, w latach 2006-2016. Do przedstawienia wyników wykorzystano mierniki opracowane przez ekspertów Światowego Forum Ekonomicznego, w szczególności wielowymiarowy Indeks Globalnej Konkurencyjności. Przedstawione zostaną także czynniki konkurencyjności w podziale na czynniki wzmacniające i obniżające konkurencyjność Litwy.

Na rysunku 5. przedstawiono zmianę pozycji krajów bałtyckich na podstawie Indeksu Globalnej Konkurencyjności (GCI). Według WEF najbardziej konkurencyjna jest gospodarka Estonii, która w analizowanym okresie zajmowała relatywnie lepsze pozycje.

Rysunek 1. Zmiana pozycji krajów bałtyckich w rankingach konkurencyjności WEF w latach 2006-2016

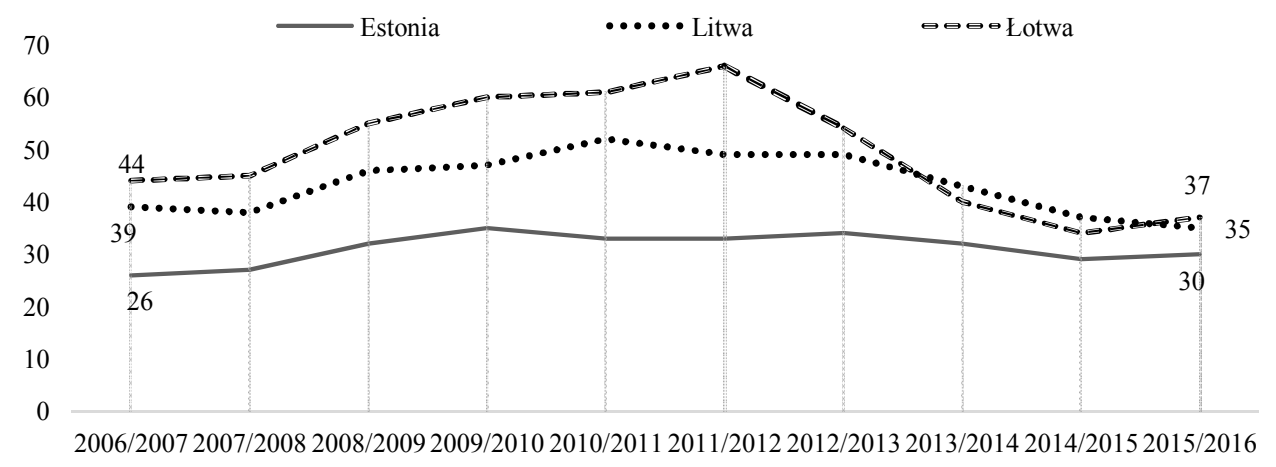

Źródło: The Global Competitiveness Reports. 
Gospodarka litewska miała lepsze wyniki niż gospodarka łotewska - w 2010 roku Litwa była na 52 pozycji, lecz po pięciu latach awansowala aż o 17 pozycji, zajmując 35 miejsce w rankingu. W gorszej sytuacji znajduje się gospodarka łotewska. Wszystkie trzy gospodarki odnotowały znaczący spadek w latach 2009-2012. Głębsza analiza każdego z ujetych w rankingu czynników konkurencyjności kraju w odniesieniu do innych krajów pozwala też na ustalenie, które czynniki w przypadku danego kraju są jego silną stroną, a które słabą, i jak się zmienia ich znaczenie. Rankingi uwypuklają raczej znaczenie pewnych czynników ważnych dla kształtowania określonej pozycji konkurencyjnej danej gospodarki w przyszłości, nie akcentując tak bardzo osiągniętej pozycji.

$\mathrm{Z}$ tabeli 4 wynika, że w przypadku Litwy wskaźniki są znacznie gorsze niż w przypadku Estonii. Do filarów wzmacniających gospodarkę Litwy można zaliczyć następujące filary: F2 - infrastruktura i F5 - edukacja wyższa i szkolenia. W przypadku filaru 5 zajmowana pozycja nieznacznie się zmieniała w latach 2006-2016. Najlepszy wynik był w latach 2015-2016, 24 miejsce, a najgorszy w latach 2009-2010. W przypadku filaru 2 także odnotowano nieznaczne zmiany pozycji - 43 miejsce w 2006 roku i 42 w roku 2016.

Najbardziej problemowymi obszarami litewskiej gospodarki są filary: F7 - efektywność rynku pracy, F8 - rozwój rynku finansowego oraz F10 - wielkość rynku (rys. 2).

Tabela 4. Zmiany czynników wzmacniających konkurencyjność litewskiej gospodarki według WEF w latach 2006-2016

\begin{tabular}{|c|c|c|c|c|c|c|c|c|c|c|c|c|c|}
\hline \multirow{2}{*}{\multicolumn{2}{|c|}{ Lata }} & \multicolumn{12}{|c|}{ Filary konkurencyjności } \\
\hline & & \multirow{2}{*}{$\begin{array}{c}1 \\
58\end{array}$} & \multirow{2}{*}{$\begin{array}{c}2 \\
43\end{array}$} & \multirow{2}{*}{$\frac{3}{25}$} & \multirow{2}{*}{$\begin{array}{l}4 \\
42\end{array}$} & \multirow{2}{*}{$\frac{5}{28}$} & \multirow{2}{*}{$\begin{array}{c}6 \\
50\end{array}$} & \multirow{2}{*}{$\frac{7}{43}$} & \multirow{2}{*}{$\begin{array}{c}8 \\
51\end{array}$} & \multirow{2}{*}{$\frac{9}{40}$} & \multirow{2}{*}{$\frac{10}{64}$} & \multirow{2}{*}{$\begin{array}{l}11 \\
43\end{array}$} & \multirow{2}{*}{$\begin{array}{l}12 \\
45\end{array}$} \\
\hline 2006 & M & & & & & & & & & & & & \\
\hline 2007 & W & 3,8 & 4,0 & 5,6 & 6,2 & 4,9 & 4,4 & 4,4 & 3,4 & 3,8 & 3,8 & 4,3 & 3,4 \\
\hline \multirow{2}{*}{$\begin{array}{l}2007 \\
2008\end{array}$} & $\mathrm{M}$ & 58 & 48 & 38 & 43 & 25 & 44 & 44 & 54 & 38 & 67 & 42 & 48 \\
\hline & W & 4,1 & 4,1 & 5,3 & 5,8 & 5,0 & 4,5 & 4,5 & 4,6 & 4,0 & 3,4 & 4,4 & 3,4 \\
\hline \multirow{2}{*}{$\begin{array}{l}2008 \\
2009\end{array}$} & M & 55 & 46 & 52 & 52 & 26 & 48 & 49 & 56 & 38 & 69 & 49 & 44 \\
\hline & W & 4,2 & 4,2 & 5,2 & 5,7 & 4,9 & 4,5 & 4,5 & 4,5 & 4,3 & 3,5 & 4,4 & 4,4 \\
\hline \multirow{2}{*}{$\begin{array}{l}2009 \\
2010\end{array}$} & $\mathrm{M}$ & 59 & 43 & 57 & 55 & 30 & 59 & 45 & 72 & 36 & 69 & 56 & 53 \\
\hline & W & 4,0 & 4,4 & 4,7 & 5,6 & 4,8 & 4,3 & 4,6 & 4,2 & 4,5 & 3,6 & 4,2 & 4,3 \\
\hline \multirow{2}{*}{$\begin{array}{l}2010 \\
2011\end{array}$} & M & 60 & 43 & 71 & 52 & 25 & 73 & 48 & 89 & 33 & 77 & 49 & 47 \\
\hline & W & 4,0 & 4,6 & 4,6 & 5,9 & 51 & 4,1 & 4,6 & 4,0 & 4,5 & 3,5 & 4,2 & 4,4 \\
\hline \multirow{2}{*}{$\begin{array}{l}2011 \\
2012\end{array}$} & M & 62 & 43 & 73 & 46 & 26 & 64 & 54 & 89 & 34 & 79 & 54 & 44 \\
\hline & W & 3,9 & 4,6 & 4,7 & 6,0 & 5,1 & 4,3 & 4,5 & 3,9 & 4,7 & 3,5 & 4,1 & 4,4 \\
\hline
\end{tabular}




\begin{tabular}{|c|c|c|c|c|c|c|c|c|c|c|c|c|c|}
\hline \multirow{2}{*}{$\begin{array}{l}2012 \\
2013\end{array}$} & $\mathrm{M}$ & 60 & 40 & 75 & 39 & 26 & 56 & 65 & 87 & 33 & 74 & 56 & 45 \\
\hline & W & 4,0 & 4,7 & 4,6 & 6,1 & 5,1 & 4,4 & 4,4 & 3,9 & 5,0 & 3,5 & 4,2 & 4,4 \\
\hline \multirow{2}{*}{$\begin{array}{l}2013 \\
2014\end{array}$} & $\mathrm{M}$ & 61 & 41 & 58 & 50 & 27 & 49 & 59 & 87 & 35 & 78 & 48 & 48 \\
\hline & W & 4,0 & 4,7 & 4,9 & 6,0 & 5,2 & 4,4 & 4,3 & 3,8 & 4,8 & 3,6 & 4,3 & 4,4 \\
\hline \multirow{2}{*}{$\begin{array}{l}2014 \\
2015\end{array}$} & $\mathrm{M}$ & 58 & 43 & 42 & 35 & 26 & 47 & 53 & 65 & 28 & 77 & 49 & 41 \\
\hline & W & 4,0 & 4,7 & 5,3 & 6,2 & 5,3 & 4,6 & 4,3 & 4,1 & 5,4 & 3,6 & 4,3 & 4,5 \\
\hline \multirow{2}{*}{$\begin{array}{l}2015 \\
2016\end{array}$} & $\mathrm{M}$ & 53 & 42 & 30 & 36 & 24 & 36 & 53 & 57 & 22 & 78 & 39 & 36 \\
\hline & W & 4,1 & 4,7 & 5,6 & 6,2 & 5,3 & 4,6 & 4,3 & 4,0 & 5,6 & 3,6 & 4,3 & 4,5 \\
\hline
\end{tabular}

* M-miejsce, $\mathrm{W}$ - wartość.

Źródło: The Global Competitiveness Reports.

Rysunek 2. Czynniki (filary) osłabiające konkurencyjność gospodarki litewskiej w latach 2006-2016

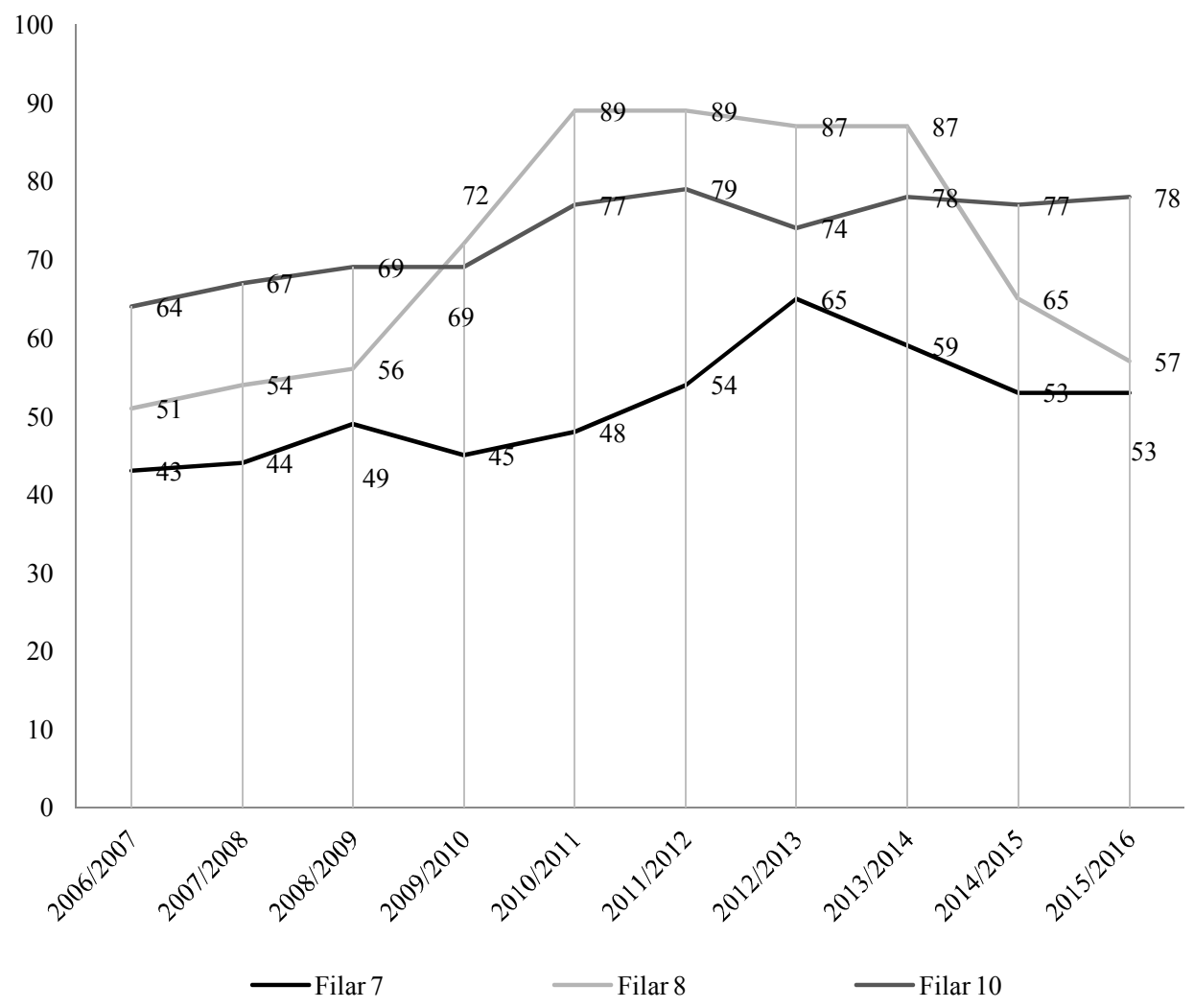

Źródło: The Global Competitiveness Reports. 
W przypadku filaru 7 pozycja konkurencyjności litewskiej gospodarki spadła w latach 2006-2016 o 10 miejsc. Analizując powyższe dane, można zauważyć, że w przypadku filaru 8 najlepsza pozycja była w 2006 roku, a najgorsza w latach 2010-2012 (89 miejsce). Gorzej jest w przypadku filaru 10 - w latach 2006-2007 gospodarka litewska była na 64 miejscu, a w latach 2015-2016 spadła o 14 pozycji i uplasowala się na 78 miejscu. Eksperci odnotowują, że Litwa powinna się skupić na zwiększeniu efektywności ram prawnych w rozstrzyganiu sporów, zmniejszeniu ciężaru regulacji rządowych oraz na rozwoju klastrów, analizie wpływu opodatkowania na napływ BIZ, a tak że na motywacji do pracy.

\section{Kapitał ludzki jako czynnik międzynarodowej konkurencyjności litewskiej gospodarki}

Kapitał ludzki jest uważany za kluczowy czynnik kształtujący poziom konkurencyjności gospodarek, co bezpośrednio wiąże się z rozwojem gospodarki opartej na wiedzy. Jego jakość i wartość muszą pozostawać na wysokim poziomie, tak aby procesy tworzenia i transferu wiedzy przebiegały bez zakłóceń. Kapitał ludzki traktowany jest jako istotny czynnik rozwoju regionalnego krajów Unii Europejskiej, w tym Litwy.

W tabeli 5 przedstawiono zmianę pozycji gospodarki litewskiej oraz innych wybranych krajów na podstawie Indeksu Kapitału Ludzkiego (Human Capital Index). Według najnowszego The Human Capital Report 2016, dotyczącego kapitału ludzkiego 130 gospodarek, najbardziej konkurencyjną gospodarką świata w kontekście kapitału ludzkiego jest Finlandia.

Tabela 5. Pozycja krajów bałtyckich na tle innych wybranych krajów świata w rankingach WEF według kapitału ludzkiego w latach 2013, 2015 i 2016

\begin{tabular}{|l|c|c|c|c|}
\hline Państwa & 2013 & 2015 & 2016 & Zmiana 2013-2016 \\
\hline Litwa & 34 & 18 & 21 & +13 \\
\hline Lotwa & 38 & 23 & 27 & +11 \\
\hline Estonia & 27 & 16 & 15 & +12 \\
\hline Rosja & 51 & 26 & 28 & +23 \\
\hline USA & 16 & 17 & 24 & -8 \\
\hline Chiny & 43 & 64 & 71 & +28 \\
\hline Finlandia & 2 & 1 & 1 & +19 \\
\hline Polska & 49 & 28 & 30 & +1 \\
\hline
\end{tabular}

Źródło: The Human Capital Report (2013), The Human Capital Report (2015), The Human Capital Report (2016). 
Aby określić rolę kapitału ludzkiego w kształtowaniu konkurencyjności krajów bałtyckich bardziej szczegółowo, należy przyjrzeć się dwóm filarom konkurencyjności opisującym najważniejsze elementy kapitału ludzkiego: filarowi 4 - zdrowie i edukacja podstawowa oraz filarowi 5 - edukacja wyższa i szkolenia. W poniższym zestawieniu przedstawiono zmiany pozycji gospodarek krajów bałtyckich w odniesieniu do tych dwóch filarów w latach 2006-2016 na podstawie rankingów WEF (tabela 6).

Tabela 6. Zmiany pozycji w rankingach WEF 4 i 5 filaru konkurencyjności

\begin{tabular}{|c|c|c|c|c|c|c|c|c|c|}
\hline & \multicolumn{3}{|c|}{ Estonia } & \multicolumn{3}{|c|}{ Litwa } & \multicolumn{3}{|c|}{ Lotwa } \\
\hline & 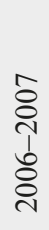 & 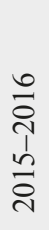 & 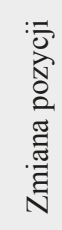 & $\begin{array}{l}\hat{\delta} \\
\text { i } \\
1 \\
\delta \\
\delta \\
\text { ㅇ }\end{array}$ & 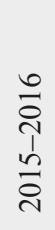 & 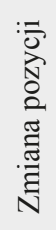 & $\begin{array}{l}\hat{\delta} \\
\text { i } \\
1 \\
\delta \\
\delta \\
\text { i }\end{array}$ & 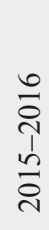 & 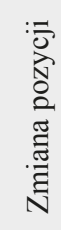 \\
\hline $\begin{array}{l}\text { Filar } 4 \text { - zdrowie } \\
\text { i edukacja podstawowa }\end{array}$ & 36 & 22 & +14 & 42 & 36 & +6 & 49 & 37 & +12 \\
\hline $\begin{array}{l}\text { Filar } 5 \text { - edukacja } \\
\text { wyższa i szkolenia }\end{array}$ & 23 & 20 & +3 & 28 & 24 & +4 & 29 & 32 & -3 \\
\hline
\end{tabular}

Źródło: The Global Competitiveness Reports.

Najlepsze wyniki w obu filarach osiąga gospodarka estońska. W przypadku Litwy notowania w zakresie zdrowia i edukacji podstawowej są obecnie bardzo podobne. W przypadku Łotwy należy odnotować duży awans w zakresie zdrowia i edukacji podstawowej, jednak znacznie lepiej oceniono litweską edukację wyższą i szkolenia oceniono (rys. 3).

$\mathrm{Z}$ przedstawionych danych wynika, że $\mathrm{w}$ analizowanym okresie zachodziły istotne zmiany, jeśli chodzi o filar 4. W latach 2006-2010 systematycznie pogarszała się sytuacja w zakresie zdrowia i edukacji podstawowej, odnotowano zatem spadek z pozycji 42 do 55 . Kolejne trzy lata przyniosły pozytywne zmiany - pozycja Litwy wzrosła o 19 miejsc, jednak już rok później miał miejsce ponowny spadek, na 50 pozycję. W ostatnich dwóch zestawieniach Litwa plasowała się na miejscach 35 i 36. Można także zauważyć, że najlepszą pozycję, jeśli chodzi o filar 4, Litwa zajęła w 2015 roku, a najgorszą - w latach 2009/2010.

Lepsza sytuacja występuje w przypadku filaru 5. W latach 2009-20010 gospodarka litewska była na 30 miejscu, a w latach 2015-2016 na 24 miejscu, czyli nastąpił wzrost o 6 pozycji. Zmiany pozycji w całym analizowanym okresie były znacznie łagodniejsze niż w przypadku 4 filara. 
Rysunek 3. Filary konkurencyjności (4 i 5) gospodarki litewskiej według WEF w latach 2006-2016 (pozycja w rankingu)

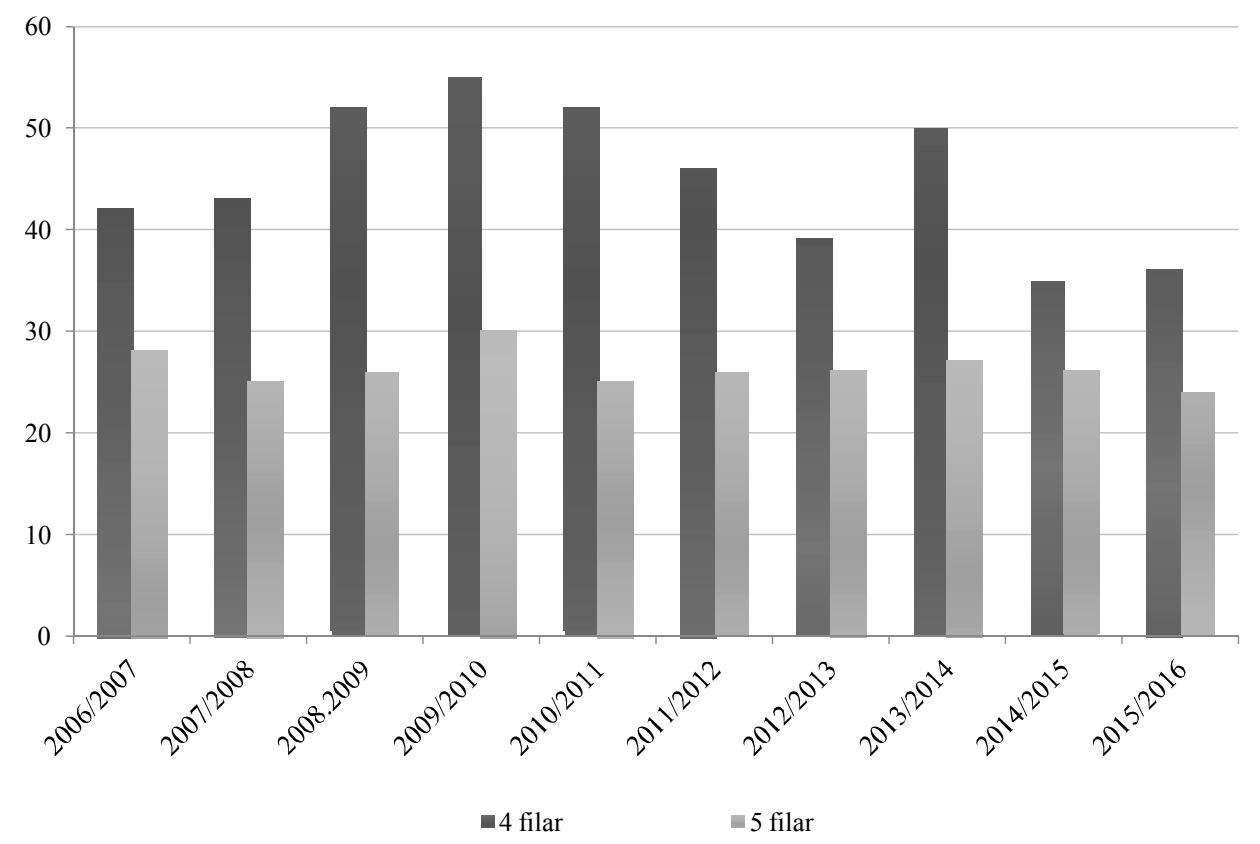

Źródło: The Global Competitiveness Reports.

Z przeprowadzonej analizy dwóch filarów konkurencyjności odnoszących się do najważniejszych elementów kapitału ludzkiego gospodarki litewskiej wynika, że pozycja Litwy w analizowanym okresie relatywnie się polepszyła. Świadczy o tym fakt, że Litwa zajmuje obecnie wyższe pozycje w rankingach WEF. Mimo stosunkowo niewielkich zmian gospodarka litewska znalazła się w grupie 50 najbardziej konkurencyjnych gospodarek świata.

\section{Podsumowanie}

Celem niniejszego artykułu było przedstawienie kapitału ludzkiego jako czynnika determinującego poziom konkurencyjności gospodarki litewskiej.

$\mathrm{Z}$ analizy porównawczej międzynarodowej konkurencyjności gospodarki Litwy można wnioskować, że mimo znaczącego pogorszenia sytuacji w czasie kryzysu gospodarka litewska odnotowała w ostatnich latach pozytywne zmiany, zajmując w 2016 roku 35 pozycję w światowym rankingu konkurencyjności.

Określenie roli kapitału ludzkiego w kształtowaniu konkurencyjności Litwy wymagało pogłębionej analizy dwóch filarów konkurencyjności odnoszących się 
do najważniejszych elementów kapitału ludzkiego: filaru 4 - zdrowie i edukacja podstawowa oraz filaru 5 - edukacja wyższa i szkolenia. Analiza pokazała, że $\mathrm{w}$ analizowanym okresie pozycja Litwy w tych obszarach relatywnie się polepszyła. Świadczy o tym zajęcie wyższej pozycji w rankingach WEF.

Z powyższych rozważań wynika, że w badanym okresie Litwa znajdowała się w gronie 50 najbardziej konkurencyjnych gospodarek świata, z ogólną tendencją wzrostu pozycji konkurencyjnej w odniesieniu do pozostałych krajów. W przypadku rankingów kapitału ludzkiego pozycja gospodarki litewskiej nie pogorszyła się - uplasowała się ona w gronie 30 najlepszych gospodarek świata. Można zatem wnioskować, że kapitał ludzki stanowi istotną determinantę konkurencyjności gospodarki litewskiej.

\section{Bibliografia}

Borowski J. (2015), Koncepcje teoretyczne konkurencyjności międzynarodowej, „Optimum. Studia Ekonomiczne” nr 4.

Bossak J., Bieńkowski W. (2004), Międzynarodowa zdolność konkurencyjna kraju i przedsiębiorstw. Wyzwania dla Polski na progu XXI wieku, Szkoła Główna Handlowa w Warszawie - Oficyna Wydawcza, Warszawa.

Domański S. R. (1993), Kapital ludzki i wzrost gospodarczy, PWN, Warszawa.

Falkowski K. (2013), Międzynarodowa konkurencyjność gospodarek Białorusi, Rosji i Ukrainy, Szkoła Główna Handlowa w Warszawie - Oficyna Wydawcza, Warszawa.

Firszt D., Jabłoński Ł. (2016), Kapitat ludzki i innowacje a zmniejszanie luki rozwojowej między krajami, CeDeWu sp. z o.o., Warszawa.

Listwan T. (2005), Stownik zarzadzania kadrami, Wydawnictwo C.H. Beck, Warszawa.

Misala J. (2007), Międzynarodowa zdolność konkurencyjna i międzynarodowa konkurencyjność gospodarki narodowej, Politechnika Radomska, Warszawa.

OECD, www.oecd.org/general/searchresults/?q=competitiveness (data dostępu: 15 maja 2016).

Schultz T. (2001), Investing In People. The Economics of Population Quality, University of California.

Schultz T. (2014), Ekonomia kapitatu ludzkiego, Oficyna a Wolters Kluwer business, Warszawa.

The Global Competitiveness Reports, www.weforum.org/reports (data dostępu: 1 czerwca 2017).

The Human Capital Report (2013), http://reports.weforum.org/human-capitalindex-2013 (data dostępu: 2 czerwca 2017).

The Human Capital Report (2015), www3.weforum.org/docs/WEF_Human_ Capital_Report_2015.pdf (data dostępu: 2 czerwca 2017). 
The Human Capital Report (2016), http://reports.weforum.org/human-capitalreport-2016 (data dostępu: 2 czerwca 2017).

World Economic Forum, www.weforum.org/agenda/2016/09/what-is-competitiveness (data dostępu: 15 maja 2016).

Woźniak M.G. (2008), Wzrost Gospodarczy. Podstawy teoretyczne, Wydawnictwo Uniwersytetu Ekonomicznego w Krakowie, Kraków.

Wronowska G. (2012), Kapitał ludzki ujęcie teoretyczne, Wydawnictwo Uniwersytetu Ekonomicznegow Krakowie, Kraków.

\section{Streszczenie}

Głównym celem każdej gospodarki jest osiągnięcie mocnej pozycji konkurencyjnej, a to w coraz większym stopniu zależy od kapitału ludzkiego. Celem artykułu jest przedstawienie kapitału ludzkiego jako czynnika o istotnym wpływie na kształtowanie się międzynarodowej pozycji konkurencyjnej litewskiej gospodarki w latach 2006-2016. W artykule posłużono się danymi pochodzącymi $\mathrm{z}$ raportów WEF.

Artykuł składa się z trzech części. Pierwsza z nich została poświęcona teoretycznym aspektom konkurencyjności międzynarodowej oraz kapitału ludzkiego. W drugiej części zbadano zmiany pozycji konkurencyjnej gospodarki litewskiej w latach 2006-2016 na podstawie Indeksu Globalnej Konkurencyjności. W części końcowej przeanalizowano kapitał ludzki Litwy w latach 2006-2016 oraz wskazano, na podstawie raportów WEF, obszary problemowe dotyczące jego jakości.

Z przeprowadzonej analizy można wywnioskować, że kapitał ludzki jest istotnym elementem konkurencyjności litewskiej gospodarki, o czym świadczy pozycja Litwy w rankingach WEF zarówno pod względem konkurencyjności, jak i jakości kapitału ludzkiego.

Słowa kluczowe: międzynarodowa konkurencyjność gospodarki, kapitał ludzki, gospodarka litewska

\section{Summary}

\section{International competitiveness of Lithuania and human capital}

The main goal of any economy is to have a strong competitive position, which is increasingly dependent on human capital. The purpose of this article is to present human capital as a factor that influences the international competitiveness of the Lithuanian economy in the years 2006-2016. To achieve this goal reports WEF were used. 
This article consists of three parts. The first one is devoted to theoretical aspects of international competitiveness and human capital. The second part examines changes in the competitive position of the Lithuanian economy in the period 2006-2016 based on the Global Competitiveness Index prepared by the WEF. Finally, the last part presents an analysis of Lithuania's human capital in the years 2006-2016 and the problems that occur.

From the analysis of international competitiveness and human capital, it can be concluded that human capital is an important determinant of the competitiveness of the Lithuanian economy. It is also worth noting that Lithuania has been ranked among the 50 most competitive economies in the world.

Keywords: international competitiveness of the economy, human capital, Lithuanian economy

JEL: J24, O15 